San Martín-Rodríguez, L., Escalada-Hernández, P., \& Soto-Ruiz, N. (2020). A themed game to learn about nursing theories and models: A descriptive study. Nurse Education in Practice, 49, 102905. https://doi.org/10.1016/j.nepr.2020.102905

\title{
A THEMED GAME TO LEARN ABOUT NURSING THEORIES AND MODELS: A DESCRIPTIVE STUDY
}

\section{Leticia San Martín-Rodríguez, $\mathrm{PhD}, \mathrm{RN}$}

Associate professor, Department of Health Sciences, Public University of Navarre (UPNA). E-mail: leticia.sanmartin@unavarra.es @1eticiasmartin

Paula Escalada-Hernández, $\mathrm{PhD}, \mathrm{RN}$

Assistant professor, Department of Health Sciences, Public University of Navarre (UPNA). E-mail: paula.escalada@unavarra.es@Pau_Climbing

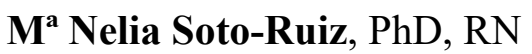

Assistant professor, Department of Health Sciences, Public University of Navarre (UPNA). E-mail: nelia.soto@unavarra.es @NelySoto4

Corresponding Author: Dr Escalada-Hernández, Department of Health Sciences, Public University of Navarre. Avda. Barañain S/N - 31008 Pamplona, (Navarra) SPAIN, (paula.escalada@unavarra.es)

(1) Funding Source: This research did not receive any specific grant from funding agencies in the public, commercial, or not-for-profit sectors.

(2) Conflict of Interest: "None declared

(C) 2020. This manuscript version is made available under the CC-BY-NC-ND 4.0 license http://creativecommons.org/licenses/by-nc-nd/4.0/ 
San Martín-Rodríguez, L., Escalada-Hernández, P., \& Soto-Ruiz, N. (2020). A themed game to learn about nursing theories and models: A descriptive study. Nurse Education in Practice, 49, 102905. https://doi.org/10.1016/j.nepr.2020.102905

\begin{abstract}
One of the most demanding challenges for teachers in undergraduate nursing programmes is teaching the intangible aspects of the discipline, such as its conceptual and theoretical bases. This study aimed to evaluate nursing students' satisfaction and knowledge acquisition after taking part in a specific themed game to learn about nursing theories and models.

A descriptive, cross-sectional, quantitative, interventional study was undertaken involving 105 nursing degree students. After taking part in a themed game called "The Nurse Theorist game", the knowledge acquired by the students was assessed plus their satisfaction with the game. The data was analysed using descriptive statistics. The results indicated that the average score for knowledge was 8.28 points (on a scale of 0 to 10); the overall average score for satisfaction was 7.60 points out of 10 . The scores obtained for satisfaction with each aspect of the game ranged from 2.90 to 3.90 out of 5 . All the students recommended using this game for this subject in the years to come. To conclude, the proposal for a themed game specifically for learning nursing theories and models has been revealed to be effective in terms of knowledge acquisition and student satisfaction.
\end{abstract}

Key words: Education; Gamification; Nursing Education Research; Nursing students; Nursing theory; 
San Martín-Rodríguez, L., Escalada-Hernández, P., \& Soto-Ruiz, N. (2020). A themed game to learn about nursing theories and models: A descriptive study. Nurse Education in Practice, 49, 102905. https://doi.org/10.1016/j.nepr.2020.102905

\section{$\underline{\text { INTRODUCTION/BACKGROUND }}$}

Within the context of higher education, different teaching methodologies, considered to be "more innovative", are emerging, such as the flipped classroom, competency-based education, collaborative learning, hands-on learning or gamification. Each with their own unique and specific features to improve the learning processes, they have varying effects on students' activity (Zepeda Hernández et al., 2016). Implementation of these emerging teaching approaches will be advantageous in any degree as evidence shows that in a traditional lecture, the learning process is interrupted within 10 to 20 minutes of the sessions starting, when the student switches off from the content being taught by the teacher (Bunce et al., 2010).

“The Horizon Report 2019”, published by the New Media Consortium (Alexander et al., 2019), explores the technological tendencies expected to be developed in the short, medium and long term in the higher education field. Among the different innovative methodologies, according to this report, gamification has been considered a powerful strategy to motivate students and promote learning. In fact, despite teachers generally considering games to be beneficial for learning, their use is still extremely limited (Alexander et al, 2019; Blakely et al., 2010; Lozada Ávila and Betancur Gómez, 2018).

Gamification consists of using techniques to design games and elements of games in non-recreational contexts (Deterding et al., 2011) to get people involved, motivate action, promote learning and solve problems (Caporarello et al., 2017). According to Hays (2005), a game is "an artificially constructed, competitive activity with a specific goal, a set of rules and constraints that is located in a specific context" (p. 15). By 
San Martín-Rodríguez, L., Escalada-Hernández, P., \& Soto-Ruiz, N. (2020). A themed game to learn about nursing theories and models: A descriptive study. Nurse Education in Practice, 49, 102905. https://doi.org/10.1016/j.nepr.2020.102905

nature, games are competitive, thereby differentiating them from other learning strategies such as simulation and role-playing (Horsley, 2010).

The use of elements from games, such as missions or challenges with other users, rewards for goals, scores and levels, improves the learning experience (Hursen and Bas, 2019; Gentrly et al., 2019; Llorens-Largo et al., 2016). Learning thereby becomes more attractive and fun, increasing student motivation and improving their involvement in their own learning, also enhancing the student-teacher relationship (Gentrly et al., 2019; Nistor and Iacob, 2018).

In the specific field of nursing education, a change from classic teaching methodologies has been promoted over the last few years, moving towards more active learning strategies such as the use of games (Royse and Newton, 2007). Many studies assess the concept of including games in nursing learning, although the majority refer to virtual games to acquire clinical skills such as decision-making or clinical judgment (Johnsen et al., 2016; Monti Fonseca et al., 2015; Petit dit Dariel et al., 2013). However, one of the most demanding challenges for teachers in undergraduate nursing programs is teaching the more intangible aspects, such as the conceptual and theoretical bases of the discipline. Learning the theoretical and conceptual content of the nursing discipline is an essential aspect that allows nursing students to understand the unique nature of their knowledge corpus and scope of practice, preparing the groundwork to develop their professional identity (Donohue-Porter et al., 2011; Rega et al., 2017; Yancey, 2015). At our university, this content has typically been taught through the traditional lecture method and completed by collaborative workshops including activities such as working on videos, debates, etc. 
San Martín-Rodríguez, L., Escalada-Hernández, P., \& Soto-Ruiz, N. (2020). A themed game to learn about nursing theories and models: A descriptive study. Nurse Education in Practice, 49, 102905. https://doi.org/10.1016/j.nepr.2020.102905

International literature pays scant attention to including the study of nursing theories and models in the basic curriculum for educating nurses and even less so the strategies to be developed to teach this specific content (Donohue-Porter et al., 2011; Meleis and Price, 1988; Yancey, 2015). There is no game-based study for learning the most abstract theoretical aspects of the discipline, such as nursing models and theories, mentioned in the literature.

Considering this gap in the literature, the main aim of this study is to evaluate nursing students' satisfaction and knowledge acquisition after participating in a specific themed game to learn about Nursing Theory. As a secondary aim, the students' assessment of the game design was analysed.

\section{$\underline{\text { METHODS }}$}

A descriptive, cross-sectional, quantitative interventional study was performed to meet the objectives.

\section{Sample and Sampling}

The study population was Nursing Degree students at the Public University of Navarre, in Spain. The conveniently selected sample included 105 first-year students that were taking the "Fundamentals of Nursing" course in the second semester of 2017/2018 academic year.

\section{Intervention: The game}

The game, called "The Nurse Theorist Game", was designed by the authors who were teachers on the "Fundamentals of Nursing" course. It was set in the American Nurses 
San Martín-Rodríguez, L., Escalada-Hernández, P., \& Soto-Ruiz, N. (2020). A themed game to learn about nursing theories and models: A descriptive study. Nurse Education in Practice, 49, 102905. https://doi.org/10.1016/j.nepr.2020.102905

Association Hall of Fame (https://www.nursingworld.org/ana/about-ana/history/hall-of$\underline{\text { fame/) }}$ and its ultimate goal was to reveal a "non-nurse" impostor who had infiltrated the Hall of Fame. To reach the final goal, the students worked in groups of 4 or 5 . This introduced principles of gamification, such as the concept of a mission or challenges with other users.

To achieve the ultimate goal, the student teams had to overcome intermediate challenges over the 6-game sessions (one session a week). Each session, consisting of two phases, led them to acquire knowledge related to each of the six schools of thought described by Kérouac and colleagues (Pepin et al., 2017): School of Needs, School of the Interaction, School of Desirable Effects, School of Caring, School of Patterns and School of Learning about Health (translation by the authors).

Each session began in the classroom by launching the initial clue through the game's website. Subsequently, students worked through the game by taking a range of challenges in 6 different scenarios: 1) the actual Hall of Fame (recreated in the corridors of the School of Health Sciences), 2) the library, 3) the "press room" (recreated in a meeting room), 4) the game's Instagram profile, 5) the virtual campus and 6) different buildings on the university campus, that represented the different Schools of Thought. Figure 1 shows these 6 scenarios. Varied learning content was offered in each of these scenarios and a clue was given that helped students to progress from one scenario to another, using the game. The content and clues were presented in different ways: in the Hall of Fame and in the campus buildings, virtual content in Augmented Reality was used, generated using the HP Reveal application; in the "press room" videos were shown related to different authors; in the library, the actual documents were used 
San Martín-Rodríguez, L., Escalada-Hernández, P., \& Soto-Ruiz, N. (2020). A themed game to learn about nursing theories and models: A descriptive study. Nurse Education in Practice, 49, 102905. https://doi.org/10.1016/j.nepr.2020.102905

(books, articles, etc.); for the virtual campus, a set of interactive materials was developed, using the Genially application; photos and keywords were used on the game's Instagram account. As an example, table 1 illustrates the steps within a phase in a game session.

As the teams were solving the intermediate challenges, they earned points, thereby introducing another gamification principle: the score. The teams' scores were published in a league table every week (Figure 2). In the last game session, teams trade their points for clues to guess who the "non-nurse" impostor might be, achieving the ultimate goal of the game. On the last day of the course, the winning team received a prize (namely: our university T-shirt) as final award, another essential element of gamification principles.

\section{Variables and measuring instruments}

Data was collected on the knowledge acquired by the students immediately after each game session. To assess this knowledge, 10 test questions were drawn up for each of the six game modules (making a total of 60 questions within the game). These were multiple choice questions with five answer options and just one right answer, or true or false questions (see example in Figure 3). The possible final score ranged from 0 points (lowest possible score) to 10 points (highest possible score).

At the end of the game, student satisfaction was assessed regarding different aspects of the game. To do this, a questionnaire was developed with 7 items that focussed on the students' opinion regarding the game's contribution to acquiring and maintaining knowledge (4 items), interaction with other students and the teacher (1 item), the 
San Martín-Rodríguez, L., Escalada-Hernández, P., \& Soto-Ruiz, N. (2020). A themed game to learn about nursing theories and models: A descriptive study. Nurse Education in Practice, 49, 102905. https://doi.org/10.1016/j.nepr.2020.102905

entertainment level in the subject (1 item) and interest in the game (1 item). The items all began with the formula "To what extent ...?" and they were answered according to a Likert scale of 5 points, where 1 corresponded to the lowest score ("Not at all") and 5 to the highest score ("Maximum”). Two general questions were added to these 7 items. They asked the students to give an overall score for the game (from 0 to 10) and state how much they would recommend using it in future academic years (options: "Yes, no doubt about it", "Yes, but with changes", "I wouldn't continue with the game"). In the event of answering "Yes, but with changes", a free text field would allow the student to explain what exactly they would change. Finally, two questions collected sociodemographic data from the student: age and gender.

\section{$\underline{\text { Data collection }}$}

The immediate knowledge data was obtained as each of the 6 game modules was completed. The Socrative mobile app was used for this, where students answered the 10 assessment questions as a group. In total, responses from 101 students were recorded.

Once the sixth week of the game had been completed, the students answered the on-line questionnaire individually regarding satisfaction and socio-demographic questions, using the survey platform Survey Monkey. In this case, 77 students answered this questionnaire.

Therefore, the knowledge acquisition was evaluated over six consecutive weeks and the satisfaction in the 6th week. All this data was collected during April and May 2018. 
San Martín-Rodríguez, L., Escalada-Hernández, P., \& Soto-Ruiz, N. (2020). A themed game to learn about nursing theories and models: A descriptive study. Nurse Education in Practice, 49, 102905. https://doi.org/10.1016/j.nepr.2020.102905

\section{$\underline{\text { Data analysis }}$}

Descriptive statistics were used to analyse the data. For the quantitative variables, the central tendency measurement was calculated alongside the average and a dispersion measurement, the standard deviation (SD). In turn, the frequencies and percentages were presented to analyse the qualitative variables. No missing data was recorded. Data was analysed using the SPSS v24 programme.

\section{Ethical considerations}

This research project was approved by the Committee of Ethics, Animal Experimentation and Biosafety of the Public University of Navarra. In addition, authorisation was requested from the Faculty Dean, following usual practice in the centre.

At the start of the course, the students were informed about the structure of the game, and it was explained that they should answer a set of evaluation questions after each weekly session, to determine the impact of the game on their learning. Additionally, they were informed that the results would be made anonymous for the purpose of this study. Participation in this knowledge assessment was totally voluntary and completing it implied consent to participate.

In the same way, during the last week of the game the students were told that information concerning satisfaction with the game would be collected using an on-line anonymous questionnaire to assess the activity, and also that completion of this questionnaire was voluntary and implied consent to participate. 
San Martín-Rodríguez, L., Escalada-Hernández, P., \& Soto-Ruiz, N. (2020). A themed game to learn about nursing theories and models: A descriptive study. Nurse Education in Practice, 49, 102905. https://doi.org/10.1016/j.nepr.2020.102905

\section{$\underline{\text { RESULTS }}$}

Out of the 77 students who voluntarily answered the satisfaction questionnaire, $83.1 \%$ $(n=64)$ were aged between 18 and 19 years old, 9.1\% $(n=7)$ were aged between 20-29 years old, $2.6 \%(n=2)$ were aged between $30-39$ years old and $5.2 \%(n=4)$ were 40 years old or more. Regarding gender, $92.2 \%(n=71)$ of the students were women.

Table 2 shows the average scores and the SD obtained in the knowledge assessment. The total average score obtained was 8.36 points (possible range between 0 and 10) with an SD of 1.09. The average score of each of the 6 modules ranged from 9.27 (SD:1.08) in the "Module 1: School of Needs" to 7.42 (SD: 1.10) in the "Module 2. School of Interactions".

In relation to the satisfaction assessment, the students gave the game an overall average score of 7.60 points (SD: 1.33) out of 10 , where the lowest score was a 4 and the highest a 10. In turn, table 3 shows the score obtained for each aspect of the game being assessed ranging from 1 to 5, expressed using the average and the SD. Among the seven items being assessed, all except one received a mean score higher than 3 . The item with the highest mean score was "Promotes entertainment in learning" (3.90, SD:0,81) followed by "Game is suitable for the material" (3.77, SD: 0.88$)$. The item with the lowest mean score was "Increased knowledge on the material" (2.90, SD: $0.64)$.

Finally, 39\% of the students (n=30) answered "Yes, no doubt about it" in terms of using this game for this subject in the coming years and $61 \%(n=47)$ answered "Yes, but with changes". No student answered that they would not recommend continuing with the 
San Martín-Rodríguez, L., Escalada-Hernández, P., \& Soto-Ruiz, N. (2020). A themed game to learn about nursing theories and models: A descriptive study. Nurse Education in Practice, 49, 102905. https://doi.org/10.1016/j.nepr.2020.102905

game. The modifications that were recommended by students who answered that they would continue with the game but with changes fell into three types: 1) reduce the quantity of content being covered, 2) make changes so that groups cannot copy each other and 3) explain the dynamics better when starting the game.

\section{DISCUSSION}

In response to the study objective, satisfaction and knowledge acquisition were assessed after engagement with a specific themed game for learning nursing theories and models among first year Nursing Degree students. On one hand, the results demonstrated that knowledge acquisition by the students participating in the game was highly satisfactory. The lowest average score was 7.42 (out of 10) in module 2 and the highest was 9.27 in module 1, and the average score for all modules was 8.28 . These results could be considered as an indication that the game might be a good strategy to teach abstract theoretical aspects of a discipline, such as nursing models and theories. Also, the high scores obtained might suggest that the results of this game-based learning experience could be equally or more competitive than the results achieved from traditional lectures, in the line of the conclusions drawn by other authors (Boyle et al., 2014; Davidson and Candy, 2016). To verify this hypothesis, future studies should compare the results from both learning strategies.

Comparing these results regarding knowledge acquisition against the assessment results from the module on nursing theories and models in the previous academic year, the positive effect of the proposed game is clear. In the previous academic year, the content of this module was taught through traditional lectures and collaborative workshops 
San Martín-Rodríguez, L., Escalada-Hernández, P., \& Soto-Ruiz, N. (2020). A themed game to learn about nursing theories and models: A descriptive study. Nurse Education in Practice, 49, 102905. https://doi.org/10.1016/j.nepr.2020.102905

where students had to make a video about a Nursing Theorist. The assessment consisted of 30 multiple-choice questions and two short-answer questions. These multiple-choice questions were similar in content and style to the assessment questions of each game module. One hundred and four students completed the evaluation. The average score was 5.8 out of 10 points (SD: 1.46; range 1.7-9).

Along this line, it is worth mentioning that the grades obtained on this specific course at our university have been historically lower than grades from other courses in the Nursing degree, due to the difficulty of the contents, plus the fact that it is taught in first year, when the students may find it very difficult to understand and assimilate these concepts. It is acknowledged that, as students work through their nursing studies, they have a deeper, more integrated understanding of the scientific and theoretical aspects of the discipline (Manninen, 1998).

The satisfaction results regarding different aspects of the game were positive. Average scores over 3 points for all aspects of the game were obtained, except for one ("increased knowledge on the subject"). Regarding the slightly lower score that the students gave to the "increased knowledge on the subject" item, it should be mentioned that this might indicate that the students did not perceive an increase in knowledge on the subject. However, the high knowledge acquisition results they obtained demonstrate that their knowledge did improve. Perhaps, because they were playing a game, the students might have perceived that they were not learning, but the results confirmed that they did acquire knowledge. This comes in addition to the fact that the content of the game addresses the more intangible aspects of the discipline, which might add to the perception of not gaining knowledge. Another possible hypothesis, considering that the students were asked about 
San Martín-Rodríguez, L., Escalada-Hernández, P., \& Soto-Ruiz, N. (2020). A themed game to learn about nursing theories and models: A descriptive study. Nurse Education in Practice, 49, 102905. https://doi.org/10.1016/j.nepr.2020.102905

their perception of knowledge acquisition when they were already aware of the knowledge assessment results, is that they could interpret that they were able to answer the evaluation questions on knowledge correctly immediately after the end of the each game session, but they may doubt the integration of this knowledge.

In addition, all the students would recommend continuing with the game for future academic years, giving the game's overall assessment a high score. Similar satisfaction findings have been identified by other studies evaluating dynamic teaching strategies based on gamification (Boctor, 2013; Gómez-Urquiza et al., 2019).

Another aspect that makes this teaching approach attractive is inclusion of new technologies. Some of the resources used in the game implied the use of mobile technology, such as visualising content in Augmented Reality and social media. This can partially explain the positive results both for knowledge and satisfaction. Recent evidence supports the use of social media and Augmented Reality as educational resources. In their bibliographic review, O'Connor et al. (2018) identified the beneficial effect of using social media in nursing and midwifery education on different learning outcomes, such as knowledge and different skills. Applying Augmented Reality technology in the context of nursing student training has also demonstrated advantageous results (Garrett et al., 2018; Zhu et al., 2014).

Another point to mention is because of its features, it might be considered as an element for future experiences and studies as this game not only manages to tackle content on nursing theories and models, but also has potential for students to embrace other more cross-disciplinary skills such as teamwork and digital literacy. Teamwork is considered 
San Martín-Rodríguez, L., Escalada-Hernández, P., \& Soto-Ruiz, N. (2020). A themed game to learn about nursing theories and models: A descriptive study. Nurse Education in Practice, 49, 102905. https://doi.org/10.1016/j.nepr.2020.102905

a fundamental skill for future nursing professionals (Interprofessional Education Collaborative, 2016). The fact that the game is played by teams competing against each other means that the members must organise themselves and work as a team to tackle the different challenges being suggested. In addition, in our current context of fast technological developments, another aspect that should be tackled in nursing education is informatics, information competencies and digital literacy (Terkes et al., 2018). Incorporating new technologies into the game dynamics meant that students could work on these skills.

Possible associated costs are one of the potential barriers for the use of gamification identified in the literature (Gentry et al., 2019; Gentry et al, 2016). One positive aspect of this intervention is that it was developed at a low cost. All the technological applications being used are free (HP Reveal, Instagram and Genially) and the physical spaces where they work are the classrooms, corridors, rooms, library and buildings on the university campus. Time restrictions are perceived as another significant barrier, as planning and implementing the game requires a great time investment from the teacher (Sánchez-Mena \& Marti-Parreño, 2017; Blakely et al., 2010). We found that the investment of time and effort was considerably higher than the time required for other learning methods in the past on this same course.

Finally, in relation to students' recommendations for future implementation, it should be highlighted that two thirds of them suggested reducing the quantity of content covered through the game, making changes to stop groups copying each other and giving a better explanation of the dynamics at the start of the game. Probably due to the nature of the content being covered, the students quickly reach their saturation threshold for 
San Martín-Rodríguez, L., Escalada-Hernández, P., \& Soto-Ruiz, N. (2020). A themed game to learn about nursing theories and models: A descriptive study. Nurse Education in Practice, 49, 102905. https://doi.org/10.1016/j.nepr.2020.102905

incorporating new knowledge. It would be a good idea to bear this in mind when developing other games focussing on learning Nursing Models and Theories. In addition, following students' suggestions about offering a better explanation of the dynamics at the start of the game, in future implementation attempts, it would also be interesting to offer a more detailed explanation of the game dynamics at the beginning to facilitate more appropriate understanding of the different phases; in addition to setting up mechanisms that prevent groups from copying each other.

The inclusion of nursing theories and models in the curricula of nursing programmes has been the subject of debate among nursing scholars, and some of them have expressed their concern in the light of the trend of omitting this content in programmes (Turkel et al., 2018). They emphasised the importance of teaching the meaning of nursing science and the basis of the nursing profession from the beginning of the programmes (Turkel et al., 2018). For academics facing the challenge of teaching Nursing Models and Theories, this study suggests that gamification of the contents from this specific subject may enhance not only concept learning, but also the students' satisfaction with a course which is usually not highly valued by them. Challenge setting, use of new technologies and the competition model being proposed might be considered the three key elements to plan gamification of this kind of courses.

This study presents certain limitations. Convenience sampling could have influenced the results. However, there is no reason to think that the selected students might differ from the students who enter university to study nursing every year. The satisfaction measurement was developed using an ad hoc questionnaire. This limitation was partially mitigated by including an open-answer question. 
San Martín-Rodríguez, L., Escalada-Hernández, P., \& Soto-Ruiz, N. (2020). A themed game to learn about nursing theories and models: A descriptive study. Nurse Education in Practice, 49, 102905. https://doi.org/10.1016/j.nepr.2020.102905

The generalizability of the results of this study is limited and should be replicated in other contexts. As Hays (2005) stated, just because a specific game works with a specific population, it does not mean that all games are effective for learning in all situations. Additionally, future research should include a longitudinal assessment of knowledge retention post-intervention.

\section{CONCLUSIONS}

The proposal for a themed game specifically for learning nursing theories and models among Nursing Degree students has been revealed to be effective to acquire knowledge. In addition, student satisfaction with the game has been positive in different aspects, solidly recommending the use of the game for future academic years. Developing a game, with features such as the use of new technologies, social media and incorporating competition and completing challenges, compared to virtual games, has low budget requirements, although the teacher must invest considerable time in it. Future research recommendations include replication of the game in other contexts, taking into account the recommendations for limiting the theoretical content covered in the game, paying particular attention to explaining the game and including mechanisms that prevent groups from copying each other. 
San Martín-Rodríguez, L., Escalada-Hernández, P., \& Soto-Ruiz, N. (2020). A themed game to learn about nursing theories and models: A descriptive study. Nurse Education in Practice, 49, 102905. https://doi.org/10.1016/j.nepr.2020.102905

\section{REFERENCES}

Alexander, B., Ashford-Rowe, K., Barajas-Murph, N., Dobbin, G., Knott, J., McCormack, M., Pomerantz, J., Seilhamer, R. \& Weber, N. (2019). Horizon Report 2019 Higher Education Edition. EDU19. Retrieved May 3, 2020 from https://www.learntechlib.org/p/208644/.

Blakely, G., Skirton, H., Cooper, S., Allum, P., Nelmes, P., 2010. Use of educational games in the health professions: A mixed-methods study of educators' perspectives in the UK. Nurs. Heal. Sci. 12, 27-32. https://doi.org/10.1111/j.1442-2018.2009.00479.x

Boctor, L., 2013. Active-learning strategies: The use of a game to reinforce learning in nursing education. A case study. Nurse Educ. Pract. 13, 96-100. https://doi.org/10.1016/j.nepr.2012.07.010

Boyle, E.A., Macarthur, E.W., Connolly, T.M., Hainey, T., Manea, M., Kärki, A., Van Rosmalen, P., 2014. A narrative literature review of games, animations and simulations to teach research methods and statistics. Comput. Educ. 74, 1-14. https://doi.org/10.1016/j.compedu.2014.01.004

Bunce, D.M., Flens, E.A., Neiles, K.T., 2010. How long can students pay attention in class? A study of student attention decline using clickers. Res. Sci. Educ. 87, 1438-1443. https://doi.org/10.1021/ed100409p

Caporarello, L., Magni, M., Pennarola, F., 2017. Learning and gamification: a possible relationship? EAI Endorsed Trans. e-Learning 4, 1-8.

Collins, S., Hewer, I., 2014. The impact of the Bologna process on nursing higher education in Europe: A review. Int. J. Nurs. Stud. 51, 150-156. https://doi.org/10.1016/j.ijnurstu.2013.07.005

Davidson, S.J., Candy, L., 2016. Teaching EBP using game-based learning: improving the student experience. Worldviews Evid. Based. Nurs. 13, 285-293. https://doi.org/10.1111/wvn.12152

Deterding, S., Dixon, D., Khaled, R., Nacke, L., 2011. From game design elements to gamefulness: Defining gamification, in: MindTrek'11. Tampere, Finland. https://doi.org/10.1145/2181037.2181040

Donohue-Porter, P., Forbes, M.O., White, J.H., 2011. Nursing theory in curricula today: challenges for faculty at all levels of education. Int. J. Nurs. Educ. Scholarsh. 8. https://doi.org/10.2202/1548-923X.2225

Garrett, B.M., Anthony, J., Jackson, C., 2018. Using mobile Augmented Reality to enhance health professional practice education. Curr. Issues Emerg. eLearning 4, 10.

Gentry, S., L'Estrade Ehrstrom, B., Gauthier, A., Alvarez, J., Wortleym D., van Rijswijk, J., Car, J., Lilienthal, A., Tudor Car, L., Nikolaou, C.K., Zary, N. Serious Gaming and Gamification interventions for health professional education. Cochrane 
San Martín-Rodríguez, L., Escalada-Hernández, P., \& Soto-Ruiz, N. (2020). A themed game to learn about nursing theories and models: A descriptive study. Nurse Education in Practice, 49, 102905. https://doi.org/10.1016/j.nepr.2020.102905

Database of Systematic Reviews 2016, Issue 6. Art. No.: CD012209. https://doi.org/10.1002/14651858.CD012209.

Gentry, S.V., Gauthier, A., L'Estrade Ehrstrom, B., Wortley, D., Lilienthal, A., Tudor Car, L., Dauwels-Okutsu, S., Nikolaou, C.K., Zary, N., Campbell, J., Car, J. 2019. Serious gaming and gamification education in Health Professions: systematic review. J Med Internet Res 21, e12994. https://doi.org/10.2196/12994

Gómez-Urquiza, J.L., Gómez-Salgado, J., Albendín-García, L., Correa-Rodríguez, M., González-Jiménez, E., Cañadas-De la Fuente, G.A., 2019. The impact on nursing students" opinions and motivation of using a "Nursing Escape Room" as a teaching game: A descriptive study. Nurse Educ. Today 72, 73-76.

https://doi.org/10.1016/j.nedt.2018.10.018

Hays, R.T., 2005. The effectiveness of instructional games: a literature review and discussion, Technical Report. Naval Air Warfare Center Training Systems Division, Orlando, FL.

Horsley, T.L., 2010. Innovative learning activity. J. Nurs. Educ. 49, 363-364. https://doi.org/10.3928/01484834-20090521-02

Hursen, C., Bas, C., 2019. Use of gamification applications in science education. Int. J. Emerg. Technol. Learn. 14, 4-23.

Interprofessional Education Collaborative, 2016. Core Competencies for Interprofessional Collaborative Practice: Reforming Health Care by Transforming Health Professionals' Education. Interprofessional Education Collaborative, Whasington, DC.

Johnsen, H.M., Fossum, M., Vivekananda-Schmidt, P., Fruhling, A., Slettebø, Å., 2016. Teaching clinical reasoning and decision-making skills to nursing students: Design, development, and usability evaluation of a serious game. Int. J. Med. Inform. 94, 39-48. https://doi.org/10.1016/j.ijmedinf.2016.06.014

Llorens-Largo, F., Gallego-Durán, F.J., Villagrá-Arnedo, C.J., Compañ-Rosique, P., SatorreCuerda, R., Molina-Carmona, R., 2016. Gamificación del proceso de aprendizaje: lecciones aprendidas [Gamification of the learning process: lessons learned]. Vaep-Rita $4,25-32$.

Lozada Ávila, C., Betancur Gómez, S., 2018. La gamificación en la educación superior: una revisión sistemática [Gamification in higher education: a systematic review]. Rev. Ing. Univ. Medellín 16, 97-124. https://doi.org/10.22395/rium.v16n31a5

Meleis, A., Price, M., 1988. Strategies and conditions for teaching theoretical nursing: An international perspective. J. Adv. Nurs. 13, 592-604.

Monti Fonseca, L.M., Del' Angelo Aredes, N., Vilela Dias, D.M., Silvan Scochi, C.G., Amado Martins, J.C., Rodrigues, M.A., 2015. Serious game e-Baby: percepção dos estudantes de enfermagem sobre a aprendizagem da avaliação clínica do bebê prematuro [Serious game e-Baby: nursing students' perception on learning about 
San Martín-Rodríguez, L., Escalada-Hernández, P., \& Soto-Ruiz, N. (2020). A themed game to learn about nursing theories and models: A descriptive study. Nurse Education in Practice, 49, 102905. https://doi.org/10.1016/j.nepr.2020.102905

preterm newborn clinical assessment]. Rev. Bras. Enferm. 68, 13-19. https://doi.org/10.1590/0034-7167.2015680102p

Nistor, G.C., Iacob, A., 2018. The advantages of gamification and game-based learning and their benefits in the development of education. eLearning\&Software Educ. 1, 308-312.

O’Connor, S., Jolliffe, S., Stanmore, E., Renwick, L., Booth, R., 2018. Social media in nursing and midwifery education: A mixed study systematic review. J. Adv. Nurs. 74, 2273-2289. https://doi.org/10.1111/jan.13799

Pepin, J., Ducharme, F., Kérouac, S., 2017. La pensée infirmière, 4․ ed. Chenelière Éducation, Montreal.

Petit dit Dariel, O.J., Raby, T., Ravaut, F., Rothan-Tondeur, M., 2013. Developing the Serious Games potential in nursing education. Nurse Educ. Today 33, 1569-1575. https://doi.org/10.1016/j.nedt.2012.12.014

Rega, M.L., Telaretti, F., Alvaro, R., Kangasniemi, M., 2017. Philosophical and theoretical content of the nursing discipline in academic education: A critical interpretive synthesis. Nurse Educ. Today 57, 74-81. https://doi.org/10.1016/j.nedt.2017.07.001

Royse, M.A., Newton, S.E., 2007. How gaming is used as an innovative strategy for nursing education. Nurs. Educ. Perspect. 28, 263-267.

Sánchez-Mena, A., \& Martí-Parreño, J. 2017. Drivers and Barriers to Adopting Gamification : Teachers ' Perspectives. The Electronic Journal of E-Learning, 15, 434-443. Retrieved from https://files.eric.ed.gov/fulltext/EJ1157970.pdf

Terkes, N., Celik, F., Bektas, H., 2018. Determination of nursing students' attitudes towards the use of technology. Japan J. Nurs. Sci. 17-24. https://doi.org/10.1111/jjns.12207

Turkel, M. C., Fawcett, J., Amankwaa, L., Clarke, P. N., Dee, V., Eustace, R., ... Smith, M. C. 2018. Thoughts about Nursing curricula: dark clouds and bright lights. Nurs. Sci. Q. 3, 185-189. https://doi.org/10.1177/0894318418755734

Wilson, K.A., Bedwell, W.L., Lazzara, E., Salas, E., Burke, S.C., Estock, J.L., Orvis, K.L., Conkey, C., 2009. Relationships between game attributes and learning outcomes:

Review and research proposals. Simul. Gaming 40, 217-266.

https://doi.org/10.1177/1046878108321866

Yancey, N.R., 2015. Why teach nursing theory? Nurs. Sci. Q. 28, 274-278. https://doi.org/10.1177/0894318415599234

Zepeda Hernández, S., Abascal Mena, R., López Ornelas, E., 2016. Integración de gamificación y aprendizaje activo en el aula [Integration of gamification and active learning in the classroom]. Ra Ximhai 12, 315-325.

Zhu, E., Hadadgar, A., Masiello, I., Zary, N., 2014. Augmented reality in healthcare education: an integrative review. PeerJ 2, e469. https://doi.org/10.7717/peerj.469 